\title{
Pengaruh Kepemilikan Institusional, Corporate Social Responsibility,Ukuran Perusahaan dan Investment Opportunity Set terhadap Nilai Perusahaan
}

\author{
Alfa Mariana Bleszynski ${ }^{1}$ \\ Purwanto ${ }^{2}$ \\ Sari Widati ${ }^{3}$ \\ Fakultas Ekonomi, Universitas Veteran Bangun Nusantara ${ }^{123}$ \\ Anto.c412@gmail.com²
}

\begin{abstract}
This research aims to test the effect of institusional ownwership, corporate social responsibility, firm size and investment opportunity set to firm value of non financial company that listed at Indonesia Stock Exchange in 20152018. The sample used in the study is 151 observations of non financial companies listed on the Indonesia Stock Exchange in the period 2015 to 2018 and took a sample using purposive sampling method. The data in the study came from the secondary data obtained through technical documentation. Data analysis technique used is the classial assumption test and multiple regression with the help of SPSS 21 for windows. The data of this study was to quality the classical assumption and test the suitability of the model with an adhusted $R^{2}$ of $60,3 \%$. The results show that: institusional ownership and firm size has a no effect to corporate value; corporate social responsibility and investment opportunity set has a positive significant to corporate value.
\end{abstract}

Keyword : institusional ownership, corporate social responsibility, firm size, investment opportunity set, firm value

\section{Pendahuluan}

Memasuki era pasar bebas, persaingan dalam dunia bisnis menjadi semakin kompetitif. Setiap perusahaan dituntut untuk selalu meningkatkan nilai perusahaan. Nilai perusahaan menjadi pertimbangan bagi investor dalam menginvestasikan dananya melalui pembelian saham perusahaan. Upaya dalam meningkatkan nilai perusahaan memerlukan kerjasama antara manajemen perusahaan dengan para pemangku kepentingan (stakeholder). 
Faktor-faktor yang dapat mempengaruhi nilai perusahaan antara lain: kepemilikan institusional, corporate sosial responsibility, ukuran perusahaan dan investment opportunity set. Kepemilikan institusional adalah kepemilikan saham oleh pihak institusi atau lembaga eksternal perusahaan. Investor institusional juga memiliki kekuasaan dalam memonitoring manajer perusahaan, sehingga fokus untuk meningkatkan nilai perusahaan. Saat ini investor cenderung menanamkan modalnya pada perusahaan yang melakukan corporate social responsibility. Hal ini dikarenakan perusahaan sadar akan tanggung jawab sosial yang dimilikinya.

Ukuran perusahaan dapat menjadi faktor dalam menentukan keuntungan atau laba yang diperoleh suatu perusahaan. Semakin tinggi tingkat keuntungan atau laba perusahaan, akan membuat harga pasar saham meningkat dan diharapkan nilai perusahaan juga turut meningkat. Faktor terakhir adalah investment opportunity set. Investment opportunity set merupakan pilihan kesempatan investasi masa depan yang dapat mempengaruhi pertumbuhan aktiva perusahaan (Putri dan Rohman, 2012). Semakin tinggi nilai Investment opportunity set, maka semakin tinggi kekayaan yang dimiliki perusahaan dalam hal investasi. Hal ini akan menarik para investor untuk menanamkan modal pada perusahaan tersebut.

Tabel 1.

Kondisi Perusahaan non keuangan di Indonesia tahun 2015-2018

\begin{tabular}{lllll}
\hline \multicolumn{1}{c}{ Uraian } & \multicolumn{1}{c}{$2015(\mathrm{Rp})$} & \multicolumn{1}{c}{$2016(\mathrm{Rp})$} & $2017(\mathrm{Rp})$ & $2018(\mathrm{Rp})$ \\
\hline Rata-Rata Jumlah & 8.071 miliar & 9.346 miliar & 10.080 miliar & 9.078 miliar \\
Penjualan Saham & Rupiah & Rupiah & Rupiah & Rupiah \\
Kapitalisasi Pasar & 4.873 triliun & 4.383 triliun & 4.989 triliun & 4.862 triliun \\
\hline
\end{tabular}

Sumber : www.sahamok.com,

Berdasarkan tabel di atas dapat dilihat rata-rata jumlah penjualan saham, tidak mempengaruhi nilai kapitalisasi pasar perusahaan. Ketika penjualan saham meningkat, maka kapitalisasi pasar cenderung meningkat maupun menurun bergantung pada jumlah perusahaan pada tahun tersebut. Investor cenderung membeli saham di saat kapitalisasi pasar pada tahun sebelumnya mengalami penurunan.

Penulis memilih perusahaan non keuangan, karena perusahaan-perusahaan tersebut lebih memiliki sumber daya yang memadai dan intensif dalam mengadopsi 
peraturan, baik secara tindakan maupun perilaku dalam tanggung jawab sosial. Hal ini menjadi sektor penggerak yang penting diperekonomian Indonesia, sehingga memiliki nilai Internasional. Peneliti memilih periode tahun 2015-2018, dengan harapan dapat menggambarkan kondisi saat ini.

\section{Kajian Pustaka dan Perumusan Hipotesis}

\section{Nilai perusahaan}

Nilai perusahaan adalah suatu presepsi investor terhadap keberhasilan suatu perusahaan atau nilai pasar. Nilai perusahaan sangat penting karena dapat menggambarkan prospek serta harapan akan kemampuan dalam meningkatkan kekayaan perusahaan di masa mendatang. Salah satu alat ukur dari nilai perusahaan adalah price book value. Rasio price book value menunjukkan tingkat kemampuan perusahaan dalam menciptakan nilai terhadap jumlah modal yang diinvestasikan.

\section{Kepemilikan institusional}

Kepemilikan institusional merupakan kepemilikan saham yang dimiliki oleh pihak-pihak yang tidak terlibat langsung dalam manajemen perusahaan (Jensen dan Meckling, 1976). Kepemilikan institusional memiliki peran penting dalam memonitor manajemen, sehingga dapat mendorong peningkatan pengawasan yang lebih efektif terhadap kinerja manajer.

\section{Corporate social responsibility}

Corporate sosial responsibility adalah tinjauan bisnis yang mengakui tanggung jawab perusahaan terhadap para pemangku kepentingan dan lingkungan hidup atau alam (Horne dan Wachowicz, 2013). Manfaat dari corporate social reponsibility yang dilakukan perusahaan adalah dapat memperbaiki hubungan dengan stakeholder, meminimalisasi resiko bisnis serta dapat memperluas akses menuju sumber daya. Instrumen pengungkapan corporate social responsibility menggunakan daftar pengungkapan tanggung jawab sosial yang disusun oleh Global Reporting Initiative Generation 4 (GRI G4).

\section{Ukuran perusahaan}


Ukuran perusahaan merupakan suatu skala pengklasifikaisan besar kecilnya suatu organisasi yang didirikan oleh seseorang atau lebih (Rahma, 2014). Ukuran perusahaan dapat diartikan sebagai cerminan total aset yang dimiliki suatu perusahaan.

\section{Investment opportunity set}

Investment opportunity set menggambarkan tentang luasnya kesempatan atau peluang investasi bagi suatu perusahaan. Salah satu rasio dari investment opportunity set adalah price earning ratio (PER).

\section{Kerangka pemikiran}

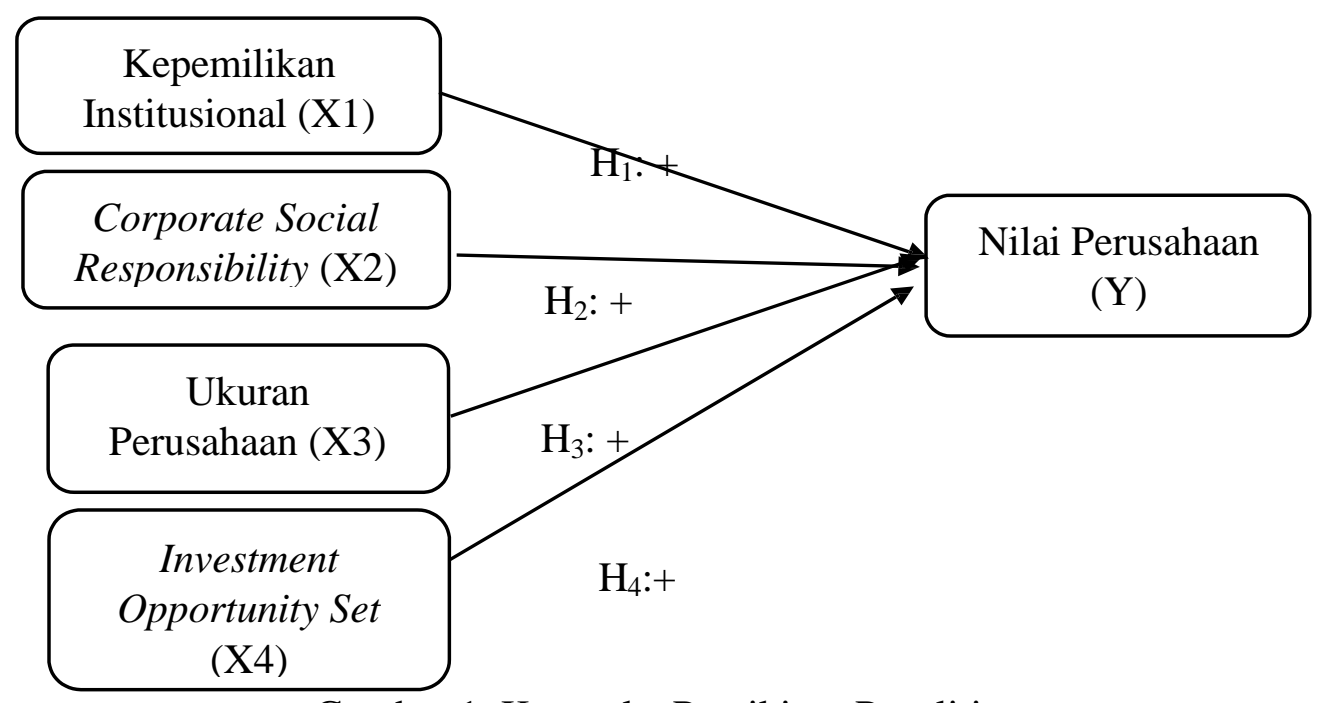

Gambar 1. Kerangka Pemikiran Penelitian

\section{Hipotesis}

Berdasarkan model kerangka penelitian diatas, maka dirumuskan hipotesis sebagai berikut:

H1: Kepemilikan institusional berpengaruh positif terhadap nilai perusahaan.

H2: Corporate social responsibility berpengaruh positif terhadap nilai perusahaan

H3: Ukuran perusahaan berpengaruh positif terhadap nilai perusahaan

H4: Investment opportunity set berpengaruh positif terhadap nilai perusahaan

\section{Metode Penelitian}

Penelitian ini mencari pengaruh dari kepemilikan institusional, corporate 
Journal of Business Finance and Economic (JBFE)

Volume 1, Nomor 1, Juni 2020

http://journal.univetbantara.ac.id/index.php/jbfe

social responsibility, ukuran perusahaan dan investment opportunity set terhadap variabel nilai perusahaan pada perusahaan non keuangan tahun 2015-2018. Data penelitian ini diolah dengan metode regresi linier berganda dengan menggunakan SPSS 21. Pemilihan sampel dilakukan dengan metode purposive sampling, yaitu pemilihan sampel berdasarkan kriteria dan sistimatika tertentu, yang bertujuan untuk mendapatkan sampel yang mendukung penelitian. Kriteria-kriteria yang menjadi faktor penentu dalam sampel penelitian ini adalah sebagai berikut:

1. Perusahaan non keuangan yang terdaftar di BEI selama periode 1 Januari 2015 sampai dengan 31 Desember 2018.

2. Perusahaan keuangan yang tidak mengalami kerugian selama periode 20152018.

3. Perusahaan non keuangan yang memiliki data lengkap atau informasi yang dibutuhkan dalam penelitian selama tahun 2015 sampai dengan 2018.

\section{Definisi Operasional dan Pengukuran Variabel}

Definisi operasional dari masing-masing variabel adalah sebagai berikut:

1. Variabel Dependen

Variabel dependen dalam penelitian ini adalah nilai perusahaan yang dilihat dari data Price Book Value (PBV). Rasio ini diperoleh dengan rumus (Brigham dan Houston, 2015):

$$
\mathrm{PBV}=\frac{\text { Harga Pasar Per Saham }}{\text { Nilai Buku Per saham }}
$$

Penelitian ini diperoleh dari data setiap akhir tahun, dari tahun 2015 hingga 2018.

2. Variabel Independen

Variabel independen dalam penelitian ini adalah Kepemilikan institusional, Corporate social responsibility, Ukuran perusahaan dan Investment opportunity set.

a. Kepemilikan Institusional (X1)

Rasio ini diperoleh dengan rumus (Wida dan Suartana, 2014)

Jumlah Saham Institusional 
Journal of Business Finance and Economic (JBFE)

Volume 1, Nomor 1, Juni 2020

http://journal.univetbantara.ac.id/index.php/jbfe

Jumlah saham yang beredar

Penelitian ini diperoleh dari data setiap akhir tahun dari tahun 2015 hingga 2018.

b. Corporate Social Responsibility (X2)

Rasio ini diperoleh dengan rumus (Rosiana, dkk, 2013)

$\mathrm{CSR}=\frac{\text { Jumlah skor item yang diungkapkan }}{\text { Jumlah skor maksimal item yang diungkapkan }}$

Penelitian ini diperoleh dari data setiap akhir tahun dari tahun 2015 hingga 2018.

c. Ukuran Perusahaan (X3)

Rasio ini diperoleh dengan rumus (Astuti, dkk, 2018)

Ukuran perusahaan $=$ Ln $($ Total Aset)

Penelitian ini diperoleh dari data setiap akhir tahun dari tahun 2015 hingga 2018.

d. Investmet Opportunity Set (X4)

Rasio ini diperoleh dengan rumus (Brigham dan Houston, 2011)

PER $=\frac{\text { Harga Pasar per saham }}{\text { Laba per saham }}$

Penelitian ini diperoleh dari data setiap akhir tahun dari tahun 2015 hingga 2018.

\section{Analisis dan Pembahasan}

Pengujian variabel independen terhadap variabel dependen dilakukan dengan uji normalitas, uji asumsi klasik, uji regresi linier berganda, uji hipotesis dan pembahasan hasil pengolahan data.

\section{Uji Normalitas}

Pengujian normalitas data dalam penelitian ini dilakukan dengan menggunakan uji Kolmogorov-Smirnov. Data yang terdistribusi normal ditunjukkan dengan nilai signifikansi diatas 0,05. Hasil dari Kolmogorov-Smirnov penelitian ini menunjukkan hasil signifikansi sebesar 0,227 atau lebih besar dari 0.05 , maka data memiliki distribusi normal.

2. Uji Asumsi Klasik

Uji asumsi klasik ini dibagi menjadi tiga yaitu uji multikolonieritas, uji autokorelasi dan uji heteroskedasstisitas.

a. Uji Multikolinieritas 
Hasil uji multikolinieritas variabel kepemilikan institusional memiliki nilai tolerance 0,930 dan nilai VIF 1,076, corporate social responsibility memiliki nilai tolerance 0,842 dan nilai VIF 1,188, ukuran perusahaan memiliki nilai tolerance 0,787 dan nilai VIF 1,270, investment opportunity set memiliki nilai tolerance 0,999 dan nilai VIF 1,001. Berdasarkan pengujian tersebut dapat disimpulkan bahwa tidak terjadi multikolinieritas.

b. Uji Autokorelasi

Metode yang digunakan adalah Runs Test, jika nilai Asymp.sig lebih besar dari 0,05 maka tidak terjadi autokorelasi. Hasil uji autokorelasi variabel kepemilikan institusional, corporate social responsibility, ukuran perusahaan dan investment opportunity set terhadap nilai perusahan menunjukkan Asymp.sig sebesar 0,369 lebih besar dari 0,05, maka data penelitian ini tidak terjadi autokorelasi.

c. Uji Heteroskedastisitas

Alat uji yang digunakan adalah Spearman's rho. Hasil uji heteroskedastisitas menunjukkan variabel kepemilikan institusional memiliki nilai signifikansi 0,831 lebih besar dari 0,05 , variabel corporate social responsibility memiliki nilai signifikansi 0,608 lebih besar dari 0,05, variabel ukuran perusahaan memiliki nilai signifikansi 0,910 lebih besar dari 0,05 dan variabel investment opportunity set memiliki nilai signifikansi sebesar 0,447 lebih besar dari 0,05, maka data penelitian ini tidak terjadi heteroskedastisitas.

3. Uji Regresi Linier Berganda

Model regresi linier berganda dapat disimpulkan layak digunakan dalam penelitian ini, karena telah terbebas dari masalah normalitas data dan asumsi klasik yang berupa multikolinieritas, autokorelasi dan heteroskedastisitas. Berdasarkan hasil pengolahan data diperoleh persamaan analisis regresi linier berganda:

$$
Y=0,940+0,287 X_{1}+1,635 X_{2}-0,034 X_{3}+0,067 X_{4}+e
$$

Berdasarkan persamaan di atas dapat dijelaskan konstanta sebesar 0,940, hal 
ini berarti apabila variabel kepemilikan institusional, corporate social responsibility, ukuran perusahaan dan investment opportunity set dianggap konstan, maka nilai variabel Nilai Perusahaan sebesar 0.940. Nilai koefisien kepemilikan institusional sebesar 0,287, hal ini menunjukkan bahwa kepemilikan institusional memiliki pengaruh positif terhadap nilai perusahaan. Kenaikan 1 satuan tingkat kepemilikan institusional, maka nilai perusahaan akan mengalami kenaikan sebesar 0,287, dengan asumsi bahwa variabel bebas yang lain dari model regresi tetap.

Nilai koefisien corporate social responsibility sebesar 1,635, hal ini menunjukkan bahwa corporate social responsibility memiliki pengaruh positif terhadap nilai perusahaan. Kenaikan 1 satuan tingkat corporate social responsibility, maka nilai perusahaan akan mengalami kenaikan sebesar 1,635, dengan asumsi bahwa variabel bebas yang lain dari model regresi tetap.

Nilai koefisien ukuran perusahaan sebesar -0,034, hal ini menunjukkan bahwa ukuran perusahaan memiliki pengaruh negatif terhadap nilai perusahaan. Kenaikan 1 satuan tingkat ukuran perusahaan, maka nilai perusahaan akan mengalami penurunan sebesar 0,034, dengan asumsi bahwa variabel bebas yang lain dari model regresi tetap. Nilai koefisien investment Opportunity Set (X5) sebesar 0,067, hal ini menunjukkan bahwa investment Opportunity Set memiliki pengaruh positif terhadap nilai perusahaan. Kenaikan 1 satuan tingkat investment opportunity set, maka nilai perusahaan akan mengalami kenaikan sebesar 0,067 dengan asumsi bahwa variabel bebas yang lain dari model regresi tetap lain adalah tetap.

\section{Uji Hipotesis}

a. $U j i R^{2}$

Uji $\mathrm{R}^{2}$ bertujuan untuk mengukur seberapa besar model regresi menerangkan pengaruh dari variabel independen terhadap variabel dependen. Koefisien determinasi variabel kepemilikan institusional, corporate sosial responsibility, ukuran perusahaan dan investment opportunity set 
terhadap variabel nilai perusahaan dapat dilihat pada tabel sebagai berikut:

Tabel 1.

Uji $\mathbf{R}^{2}$ (Koefisien Determinasi)

\begin{tabular}{ccccc} 
Model & $\mathrm{R}$ & $R$ Square & $\begin{array}{c}\text { Adjusted } R \\
\text { Square }\end{array}$ & $\begin{array}{c}\text { Std. Error of } \\
\text { the Estimate } \\
1\end{array}$ \\
$0,783^{\mathrm{a}}$ & 0,614 & 0,603 & 0,53377 \\
\hline
\end{tabular}

Sumber : Data diolah 2019

Berdasarkan tabel di atas dapat dilihat koefisien determinasi variabel independen terhadap nilai perusahaan ditunjukkan dengan nilai adjusted $\mathrm{R}^{2}$ sebesar 0,603 atau $60,3 \%$. Hal ini menunjukkan 60,3\% perubahan nilai perusahaan dipengaruhi oleh kepemilikan institusional, corporate social responsibility, ukuran perusahaan dan investment opportunity set. Sedangkan 39,7\% dijelaskan oleh faktor lain di luar model penelitian ini.

b. Uji F

Uji F bertujuan untuk mengetahui signifikansi pengaruh antara variabel independen terhadap variabel dependen secara simultan atau bersamasama. Hasil uji F variabel kepemilikan institusional, corporate social responsibility, ukuran perusahaan dan investment opportunity set terhadap variabel nilai perusahaan dapat dilihat pada tabel sebagai berikut :

Tabel 2.

Tabel Uji F

\begin{tabular}{llllll}
\hline Model & Sum of Squares & Df & Mean Square & F & Sig. \\
\hline Regression & 66,125 & 4 & 16,531 & 58,022 & $0,000^{\mathrm{b}}$ \\
Residual & 41,597 & 146 & 0,285 & & \\
Total & 107,722 & 150 & & & \\
\hline
\end{tabular}

Sumber : Data diolah 2019

Berdasarkan tabel uji F di atas didapat nilai Fhitung sebesar 58,022 dengan nilai probabilitas sebesar 0,000. Nilai probabilitas lebih kecil dari 0,05, maka model regresi dapat digunakan untuk memprediksi variabel nilai perusahaan, atau secara bersama-sama kepemilikan institusional, corporate social responsibility, ukuran perusahaan dan investment opportunity set 
berpengaruh terhadap nilai perusahaan.

c. Ujit

Uji $\mathrm{t}$ bertujuan untuk mengetahui signifikansi pengaruh antara variabel independen terhadap variabel dependen secara parsial atau individu. Apabila nilai signifikansi dibawah 0,05, maka variabel independen berpengaruh terhadap variabel dependen. Hasil uji t variabel kepemilikan institusional, corporate social responsibility, ukuran perusahaan dan investment opportunity set terhadap nilai perusahaan dapat dilihat pada tabel sebagai berikut:

Tabel 3.

\begin{tabular}{|c|c|c|c|c|c|}
\hline \multirow[b]{2}{*}{ Model } & \multicolumn{2}{|c|}{$\begin{array}{l}\text { Unstandardized } \\
\text { Coefficients }\end{array}$} & \multirow{2}{*}{$\begin{array}{l}\text { Standardized } \\
\text { Coefficients } \\
\text { Beta }\end{array}$} & \multirow[t]{2}{*}{$\mathrm{t}$} & \multirow[t]{2}{*}{ Sig. } \\
\hline & B & Std. Error & & & \\
\hline (Constant) & 0,940 & 0,986 & & 0,953 & 0,342 \\
\hline Kepemilikan Institusional & 0,287 & 0,237 & 0,064 & 1,208 & 0,229 \\
\hline $\begin{array}{l}\text { Corporate Social } \\
\text { Responsibility }\end{array}$ & 1,635 & 0,549 & 0,167 & 2,979 & 0,003 \\
\hline Ukuran Perusahaan & $-0,034$ & 0,033 & $-0,061$ & $-1,049$ & 0,296 \\
\hline Investment Opportunity Set & 0,067 & 0,005 & 0,767 & 14,918 & 0,000 \\
\hline
\end{tabular}

Sumber : Data diolah 2019

Berdasarkan tabel uji $\mathrm{t}$ di atas didapat nilai signifikansi variabel independen terhadap variabel dependen. Variabel kepemilikan institusional memiliki nilai signifikansi sebesar 0,229 yang lebih besar dari 0,05 dan nilai $t$ hitung sebesar 1,208, maka artinya kepemilikan institusional tidak berpengaruh terhadap nilai perusahaan. Kenaikan maupun penurunan pada variabel kepemilikan institusional, tidak memberikan pengaruh terhadap variabel nilai perusahaan.

Variabel corporate social responsibility memiliki nilai signifikasi sebesar 0,003 yang lebih kecil dari 0,05 dan nilai t hitung sebesar 2,979, maka berarti corporate social responsibility berpengaruh positif terhadap nilai perusahaan. Kenaikan corporate social responsibility akan meningkatkan nilai perusahaan dan penurunan corporate social responsibility akan menurunkan 
nilai perusahaan.

Variabel ukuran perusahaan memiliki nilai signifikasi sebesar 0,296 lebih besar dari 0,05 dan nilai t hitung sebesar -1,049, maka berarti ukuran perusahaan tidak berpengaruh terhadap nilai perusahaan. Kenaikan maupun penurunan pada variabel ukuran perusahaan, tidak memberikan pengaruh terhadap variabel nilai perusahaan. Variabel investment opportunity set memiliki nilai signifikasi sebesar 0,000 lebih kecil dari 0,05 dan nilai t hitung sebesar 14,918, artinya investment opportunity set berpengaruh positif terhadap nilai perusahaan. Kenaikan investment opportunity set akan meningkatkan nilai perusahaan dan penurunan investment opportunity set akan menurunkan nilai perusahaan.

d. Pembahasan

Hasil pengujian untuk variabel kepemilikan institusional, tidak berpengaruh terhadap nilai perusahaan. Hal ini berarti besar atau kecilnya kepemilikan institusional atas perusahaan, belum mampu mengontrol dan mengawasi tindakan opportunistik manajer dalam menjalankan perusahaan. Hal ini menunjukkan bahwa investor insitusional belum dapat mengoptimalkan fungsi kontrol yang dimilikinya. Oleh karena itu, strategi antara investor dan pemerintah belum mampu menjadi mekanisme untuk meningkatkan nilai perusahaan. Hasil penelitian ini sejalan dengan penelitian Warapsari dan Suryana (2016), yang menyatakan bahwa kepemilikan institusional tidak berpengaruh terhadap nilai perusahaan.

Hasil pengujian untuk variabel corporate social responsibility berpengaruh positif terhadap nilai perusahaan. Hasil penelitian ini menunjukkan bahwa kenaikan nilai corporate social responsibility, akan menaikkan nilai perusahaan, dan penurunan nilai corporate social responsibility akan menurunkan nilai perusahaan. Hal ini menunjukkan perusahaan yang bertangungjawab atas dampak negatif yang ditimbulkan selama perusahaan itu beroperasi, akan membuat investor percaya akan masa depan perusahaan tersebut. Hasil tersebut sesuai dengan hipotesis yang 
diberikan. Hasil penelitian ini memperkuat penelitian yang dilakukan oleh Nahda dan Harjito (2011), Umbara dan Suryanawa (2014), serta Murnita dan Putra (2018), yang menyatakan bahwa corporate social responsibility berpengaruh positif terhadap nilai perusahaan.

Hasil pengujian ini memberikan hasil bahwa ukuran perusahaan tidak berpengaruh terhadap nilai perusahaan. Hasil penelitian ini menunjukkan bahwa penurunan nilai ukuran perusahaan, akan menurunkan nilai perusahaan, dan kenaikan nilai ukuran perusahaan akan menaikkan nilai perusahaan. Jika perusahaan memiliki total aset yang besar, maka pihak manajemen akan mempergunakan aset dalam perusahaan tersebut untuk perluasan usaha maupun penciptaan produk baru, maka tingkat laba yang dapat didistribusikan menjadi berkurang. Laba yang mengalami penurunan, akan mengakibatkan penurunan nilai perusahaan. Hasil penelitian ini memperkuat penelitian yang dilakukan oleh Nuraina (2012) dan Israel, dkk (2018), yang menyatakan bahwa ukuran perusahaan berpengaruh negatif terhadap nilai perusahaan.

Hasil pengujian untuk variabel investment opportunity set, berpengaruh positif terhadap nilai perusahaan. Hasil penelitian ini menunjukkan bahwa kenaikan nilai investment opportunity set, akan menaikkan nilai perusahaan dan penurunan nilai investment opportunity set akan menurunkan nilai perusahaan. Hal ini karena semakin tinggi investment opportunity set, maka akan semakin tinggi kekayaan atau laba yang didapatkan perusahaan, sehingga diharapkan dapat meningkatkan nilai laba yang didistribusikan kepada para pemegang saham. Hasil tersebut sesuai dengan hipotesis yang dibuat. Hasil penelitian ini memperkuat penelitian yang dilakukan Haryanto dan Lestari (2015), Sudiani dan Darmayanti (2016) serta Hamidah dan Umdiana (2017), yang menyatakan investment opportunity set berpengaruh positif terhadap nilai perusahaan.

\section{Kesimpulan dan Saran}


Journal of Business Finance and Economic (JBFE)

Volume 1, Nomor 1, Juni 2020

http://journal.univetbantara.ac.id/index.php/jbfe

Berdasarkan hasil penelitian dan pembahasan di atas, maka penulis

mengambil kesimpulan sebagai berikut:

1. Kepemilikan institusional tidak berpengaruh terhadap nilai perusahaan. Hasil penelitian ini menolak hipotesis 1 .

2. Corporate social responsibility berpengaruh positif terhadap nilai perusahaan.

Hasil penelitian ini mendukung hipotesis 2.

3. Ukuran perusahaan tidak berpengaruh terhadap nilai perusahaan. Hasil penelitian ini menolak hipotesis 3.

4. Investment opportunity set berpengaruh positif terhadap nilai perusahaan.

Hasil penelitian ini menolak hipotesis 4.

Saran untuk penelitian selanjutnya perlu lebih memperbanyak variabel dan tahun penelitian, agar hasil yang didapat dapat lebih akurat lagi

\section{DAFTAR PUSTAKA}

Astuti, Fitria Yuni, Sugeng Wahyudi dan Wisnu Mawardi. 2018. Analysis Of Effect Of Firm Size, Institutional Ownership, Profitability, and Leverage on Firm Value with Corporate Social Responsibility (CSR) Disclosure as Intervening Variables. Jurnal Bisnis Strategi, Vol. 27, No.2, Hal.95-109

Brigham, Eugene F. dan Joel F. Houston. 2011. Dasar-dasar Manajemen Keuangan buku 1 Edisi 9. Jakarta : Salemba Empat

Ghozali, Imam. 2018. Aplikasi Analisis Multivariate dengan Program IBM SPSS 25. Semarang: Badan Penerbit Universitas Diponegoro

Giriati. 2016. Free Cash Flow, Devidend Policy, Investment Opportunity Set, Opportunistic Behavior and Firm Value. Procedia-Social and Behavioral Sciences, Vol. 21, No. 9, Hal. 248-254

Hafez, Hasan M. 2016. Corporate Social Responsibility and Firm Value : An Empirical Study of an Emerging Economy. Journal of Governance and Regulation, Vol. 5, Issue 4. Hal. 40-53

Hamidah, Ghina dan Nana Umdiana. 2017. Pengaruh Profitabilitas dan Investment Opportunity Set terhadap Nilai Perusahaan dengan Harga Saham sebagai Variabel Intervening. Jurnal Akuntansi, Vol. 3, No. 2, Hal. 90-106

Hariyanto, Marina Suzuki dan Putu Vivi Lestari. 2015. Pengaruh Struktur Kepemilikan, IOS, dan ROE terhadap Nilai Perusahaan pada Perusahaa 
Food And Baverage. E-Jurnal Manajemen Unud, Vol. 4, No. 4, Hal. 1599- 1626

Horne, James C. Van and John M. Wachowicz, Jr. 2013. Prinsip-prinsip Manajemen Keuangan buku 1 Edisi 13. Jakarta : Salemba Empat

Indriyani, Eka. 2017. Pengaruh Ukuran Perusahaan dan Profitabilitas terhadap Nilai Perusahaan. Akuntabilitas : Jurnal Ilmu Akuntansi, Vol. 10, No.2, Hal. 333-348

Israel, Cristy, Marjam Mangantar dan Ivonne S. Saerang. 2018. Pengaruh Struktur Modal, Kepemilikan Institusional dan Ukuran Perusahaan terhadap Nilai Perusahaan. Jurnal EMBA, Vol. 6, No. 3, Hal. 1118-1127

Jensen, Michael C. and William H. Meckling. 1976. Theory of the Firm: Managerial Behavior, Agency Costs and Ownership Structure. Journal of Financial Economics, Vol. 3, No. 4, Hal. 305-360

Lestari. 2017. Pengaruh Kepemilikan Institusional dan Struktur Modal terhadap Nilai Perusahaan. Jurnal Riset Manajemen dan Bisnis (JRMB) Fakultas Ekonomi UNIAT, Vol. 2, Hal. 293-306

Mehrian, Ayoub Razavi and Alireza Ghenaatpisheh. 2016. Investigating the Effect of Institutional Ownership on the Value and Risk of Variability Companies Listed on the Tehran Stock Exchange. International Academic Journal of Accounting and Financial Management, Vol. 3, No. 12, Hal. 24-29

Murnita, Putu Elia Meilinda dan I Made Pande Dwiana Putra. 2018. Pengaruh Corporate Social Responsibility terhadap Nilai Perusahaan dengan Profitabilitas dan Leverage sebagai Variabel Pemoderasi. EJurnal Akuntansi Universitas Udayana, Vol. 23, No. 2, Hal. 1470-1494

Nahda, Katiya dan D. Agus Harjito. 2011. Pengaruh Corporate Social Responsibility terhadap Nilai Perusahaan Dengan Corporate Governance Sebagai Variabel Moderasi. Jurnal Siasat Bisnis, Vol. 23, No. 1, Hal. 1-12

Nuraina, Elva. 2012. Pengaruh Kepemilikan Institusional dan Ukuran Perusahaan Terhadap Kebijakan Hutang dan Nilai Perusahaan. Jurnal Bisnis dan Ekonomi (JBE), Vol.19 No. 2, Hal. 110-125

Priyatno, Duwi. 2014. SPSS 22 : Pengolahan Data Terpraktis. Yogyakarta: Andi

Putri, Ayu Kemala, Made Sudarma dan Bambang Purnomo Sidhi. 2016. Pengaruh Corporate Social Responsibility terhadap Nilai Perusahaan dengan Ukuran Perusahaan dan Jumlah Dewan Komisaris sebagai Variabel Pemoderasi. Jurnal Aplikasi Manajemen, Vol. 14, No. 2, Hal. 344-358

Putri, Paramitha Anggia dan Abdul Rohman. 2012. Analisis Pengaruh Invesment Opportunity Set (IOS) dan Mekanisme Corporate Governance terhadap Kualitas Laba dan Nilai Perusahaan. Diponegoro Journal of Accounting,

Vol. 1, No. 2, Hal.1-14

Rahma, Alfiarti. 2014. Pengaruh Kepemilikan Manajerial, Kepemilikan Institusional dan Ukuran perusahaan terhadap Keputusan Pendanaan dan Nilai Perusahaan. Jurnal Bisnis Strategi, Vol. 23, No. 2, Hal. 45-69

Rosiana, Gusti Ayu Made Ervina, Gede Juliarsa dan Maria M. Ratna Sari. 2013. Pengaruh Pengungkapan CSR terhadap Nilai Perusahaan 
dengan Profitabilitas sebagai Variabel Pemoderasi. E-Jurnal Akuntansi Universitas Udayana, Vol. 5, No. 3, Hal:723-738

Rudangga, I Gusti Ngurah Gede dan Gede Merta Sudiarta. 2016. Pengaruh Ukuran Perusahaan, Leverage dan Profitabilitas terhadap Nilai Perusahaan. E-Jurnal Manajemen Unud, Vol. 5, No. 7, Hal. 4394-4422

Sekaran, Uma.2011. Metodologi Penelitian Untuk Bisnis. Jakarta : Salemba Empat. Hal.151-181

Sudarma, I Ketut Gede Adi Mas dan Ni Putu Ayu Darmayanti. 2017. Pengaruh CSR, Kepemilikan Managerial dan Profitabilitas terhadap Nilai Perusahaan. E-Jurnal Manajemen Unud, Vol. 6, No. 4, Hal. 19061932

Sudiani, Ni Kadek Ayu dan Ni Putu Ayu Darmayanti. 2016. Pengaruh Profitabilitas, Likuiditas, Pertumbuhan dan Investment Opportunity set terhadap Nilai Perusahaan. E-Jurnal Manajemen Unud, Vol. 5, No. 7, Hal. 4545-4574

Suharyadi dan Purwanto S. K. 2016. Statistika Untuk Ekonomi dan Keuangan Modern buku 2 Edisi 3. Jakarta : Salemba Empat

Sukoco, Heri. 2013. Analisis pengaruh Debt to Equity Ratio, Profitabilitas, Firm Size, Likuiditas terhadap Nilai Perusahaan melalui Mediasi Deviden Payout Ratio. Jurnal Bisnis Strategi,Vol. 22, No. 2, Hal. 112127

Thanatawee, Yordying. 2014. Institusional Ownership and Firm Value In Thailand. Asian Journal Of Business And Accounting, Vol. 7, No. 2, Hal. 1-22

Umbara, Dewa Made Bagus dan I Ketut Suryanawa. 2014. Pengaruh Pengungkapan Tanggung Jawab Sosial pada Nilai Perusahaan. Ejurnal Akuntansi Universitas Udayana, Vol. 9, No. 2, Hal. 410-424

Warapsari, A. A. Ayu Uccahati dan I. G. N. Agung Suaryana. 2016. Pengaruh Kepemilikan Manajerial dan Institusional terhadap Nilai Perusahaan Dengan Kebijakan Utang Sebagai Variabel Intervening. EJurnal Akuntansi Universitas Udayana, Vol.16, No. 3, Hal. 2288-2315

Wida, Ni Putu P. D. dan I Wayan Suartana. 2014. Pengaruh Kepemilikan Manajerial dan Kepemilikan Institusional pada Nilai Perusahaan. EJurnal Akuntansi Universitas Udayana, Vol. 9, No.3, Hal.575-590 